\title{
Communication Model of P2TP2A Officer in The Assisting Families Process of Sexual Violence Victims
}

\author{
Nurbani \\ Fakultas Ilmu Sosial dan Ilmu Politik \\ Universitas Sumatera Utara \\ Medan, indonesia \\ sunbanymonora@gmail.com
}

\author{
Sabariah Bangun and Abdi Sitepu \\ Fakultas Ilmu Sosial dan Ilmu Politik \\ Universitas Sumatera Utara \\ Medan, indonesia \\ bangunsabariah@gmail.com
}

\begin{abstract}
This study is titled "Communication model of P2TP2A officers in the assisting families process of sexual violence victims." P2TP2A is an integrated center of activities that provides services to women and children victims of violence, including services of Information, Psychological and Legal Consultations, and Assistance. This study illustrates how the process conducted by P2TP2A Serdang Bedagai Regency in handling cases of sexual harassment and abuse victims both organizational and approaches to victims and their families. This study uses descriptive qualitative approach. The method of this study is through non participative observation and in-depth interview. Data obtained in this study are the pattern of organizational communication among P2TP2A officers, communication process P2TP2A officers with victims and families, and the communication process barriers.
\end{abstract}

Keywords- organizational communication, communication barrier, p2tp2a, sexual violence

\section{INTRODUCTION}

According to Act No. 23 Year 2002 on Child Protection, child protection is all activities to guarantee and protect children and their rights in order to live, grow, develop and participate optimally in accordance with human dignity and values, and have protection from violence and discrimination. Then there is the special protection that protection is given to children in emergency situations, legal, minority and isolated children, economically and / or sexually exploited children, trafficked children, children who are victims of drug abuse, alcohol, psychotropic, and other addictive substances (drugs), child abductee, sales, trafficking, child victims of physical and / or mental violence, disabled children, and child victims of mistreatment and neglect.

Violations against the protection of children's rights, in addition to violations of human rights, also constitute a great deterrent to the survival and development of children. Children who are victims of violence, exploitation, abuse and neglect will have problem in life, for instance: shorter life, poor mental and physical health, educational issues (including dropping out), poor parenting skills, homeless, displaced from their homes, and homeless. On the other hand, successful protective measures will increase the chances of children growing physically and mentally healthy, confident and self-esteem, and less likely to abuse or exploit others, including their own children.

Data and Information Center of the National Commission for the Protection of Indonesian Children 2010-2014 revealed that there are more than 21 million cases of child rights violations spread in 34 provinces and 179 districts / regencies, $42-58 \%$ of which are cases of sexual crimes against children, the remaining cases of physical violence and child neglect. Cases of sexual assault against children and women are increasing. In 2012, the National Commission for Child Protection received 2,637 reports of violations against children, $62 \%$ of which were sexual violence. The number increased from 2010 , that is 2,426 cases with $42 \%$ of cases of sexual violence and in 2011 , that is 2,509 cases with $58 \%$ of cases of sexual violence (Jurnal Perempuan, 2012).

The Center for Integrated Service and Women's Empowerment and Child Protection (P2TP2A) is one of the service vehicles for women and children in the effort to fulfill information and needs in the field of education, health, economics, law, protection and prevention of violence and trafficking against women and children. The Center for Integrated Service for Women Empowerment and Child Protection (P2TP2A) is a container of integrated service delivery covering the prevention, provision and implementation of integrated services for victims covering health rehabilitation services, social rehabilitation, social reintegration and legal aid and monitoring and evaluation. As an extension of the state in protecting women and children, P2TP2A Serdang Bedagai deals with a wide range of sexual violence each year. In the process of handling cases that occur, it is important to see the pattern of communication made by the institution P2TP2A in providing services. Because the communication has made by P2TP2A institution is one of afftected factor that influence the effectiveness of handling cases of sexual violence which occurred in women and children.

Previously, the review of P2TP2A institutional has been conducted, both to measure the effectiveness of institutional performance and effective pattern in handling cases of sexual violence in women and children. As mentioned in the research results of Syawaluddin Nasution, \& Tuti Khairani (2015) The 
Performance of Integrated Service Center for Women and Children Empowerment (P2TP2A) in Handling Violence Against Women and Children in Riau Province (Case Study of Pekanbaru City), it showed that P2TP2A performance of Pekanbaru Regency deal with violence against women and children, in terms of productivity has not been good. It is proven from the results of a study shows the availability of P2TP2A staff can be compared with the number of employees required to handle the existing cases. Reciprocally, facility and infrastructure P2TP2A Pekanbaru city is still not adequate (they are still not provide operational car, shelter house, and office). The P2TP2A Responsivity Pekanbaru City is also not good, it can be seen from the results of studies that does not yet show effective socialization conducted to the community.

Indrawati (2017) Study on Integrated Service Centers for Women and Children Empowerment (P2TP2A) in Handling of Violence Against Women in Bontang District, it explains that in P2TP2A law services carry out legal aid activities to protect and assist victims in the form of legal aid, it works with police, prosecutors, courts, and religious ministries. During the legal process, both from the complaint to the court, P2TP2A officers always accompany the victim. At the stage of medical and psychological services conducted by P2TP2A has been well implemented, in cooperation with partners P2TP2A. On the restoration stage, the reintegration and safe house services, it depends on cooperation with existing partners and volunteers because P2TP2A does not have its own facilities.

Reinforced by Misriyani Hartati's (2013) Study of the Efforts to Address Violence Against Women and Children (A Case Study at Integrated Service Centers for Women and Children Empowerment (P2TP2A) East Kalimantan Province), it shows that there are still lackness in cases handling conducted by P2TP2A, both from side of quantity and quality. However there are factors supporting the handling of acts of violence against women and children that in the form of financial aid obtained from the East Kalimantan Provincial Income and Expenditure Budgets also the contributions from individuals and organizations that are not binding.

Based on the results of this study, in some areas of Indonesia there are still many shortcomings and barriers of P2TP2A institutions in preventing and handling cases of sexual violence. Most of the obstacles faced by P2TP2A institutions are the lack of facilities and the infrastructure of facilities for handling cases such as safe houses, supporting transportation, and psychological treatment of victims. In addition, regarding the quality and quantity of human resources P2TP2A institutions to perform services still do not maximum yet whether in knowledge or in number.

Serdang Bedagai as one of the districts that get the title of Child Friendly Regency in the national rank become an interesting area to do research related to institutional performance of P2TP2A also become one of indicator in process of determination of child friendly district. However, in this study the main focus is the effective communication model used and developed by institutional P2TP2A Serdang Bedagai District. The inadequacy of P2TP2A institutional facilities and infrastructure facilities such as the results of the above assessment will be least solved if P2TP2A institutions have effective communication models in providing services to the prevention and treatment of sexual violence.

\section{METHOD}

The method of effective communication of P2TP2A institution in preventing and handling of sexual violence reserach is using qualitative research method. Preliminary observations were conducted to gain an overview of the situation and conditions and to determine the issues to be studied. Research on tourism development strategy uses data collection techniques such as in-depth interview and participant observation. Indepth interviews were conducted to obtain as much information as possible about the cases of sexual violence that occurred in the victims as a whole, and the handling done by the P2TP2A Institution of Serdang Bedagai Regency.

Participant observations have been done to engage the researcher into the activities or P2TP2A officer activities in handling child sexual violence. Observation is surveillance systematically toward the symptoms that appear on the object of research. Moreover, they have to do Focus Group Discussion (FGD) to get more satisfactory result. This group discussion focused more on some victim families of sexual violence against children. The above three analytical activities are intertwined with each other before, during, and after collecting data in parallel form. The meaning is that the process does not run linearly or some sort of successive, but cyclical and interactive event. Analysis of firmly qualitative data Miles \& Huberman (1992: 20) is an ongoing, repetitive, and ongoing effort.

\section{RESULTS AND DISCUSSION}

\section{A. Integrated Service Center for the Protection of Women and Children (P2TP2A) Serdang Bedagai District in Providing Child Protection against Violence}

The services provided by the P2TP2A Technical Implementation Unit of Serdang Bedagai Regency to the victims of violence in accordance with the flow chart of the handling. Handling action to the victim may be provided by the officer if the case has been reported to this institution. After a complaint of violent cases, the officer then finds out whether there is actually a violent incident by confirming to the perpetrator or the person knowing the violence. If, at the time, A complaint of violence cases the victim came to the office, then the victim can be immediately given further treatment. However, if the victim does not participate, the officer will visit the house or place of violence to confirm. Visiting is conducted by officers beside to ensure violent incidents are actually happened also it has purpose to identify the circumstances of the victim and the environmental conditions of the victim's residence which may be a support or threat to the victims.

A good support can be done such as a good environment to live as well as those around the victim who can understand and are willing to help the victim. While the threat is included in the surrounding victim there are things that make the situation more severe victims, such as parents, relatives, or others 
around him or her constantly asked about the incident. So, it made victims depressed psychologically. In addition, environmental conditions that can make the victim back to experience violence, for example, perpetrators of violence are in one house with the victim. Until now, most cases handled by P2TP2A Serdang Bedagai still come from police referral. This is because P2TP2A has not been widely socialized in the society.

After the officer receives a complaint of a violent case, the officer identifies the need to record and observe the victim to ensure that violence has actually occurred. Needs identifications is made to the victim with the aim of assessing the physical, safety and psychological status of the victim. Assessment is done by asking the victim questions about the victim's physical condition as well as the victim's psychological situation and his security. The assessment is used to determine the attitude or subsequent action against the victim. The handling physical examination needs, institutionally P2TP2A does not have MoU with Regional Hospital, so for the handling of the visum its financing is still the responsibility of the victim.

There are victims still not in critical condition, for these kind of victims can get assistance. The assistance provided to the victims should be adjusted to the needs of the victims. This kind of assistance may be legal and non-legal assistance. Legal assistance is done by providing information related to the legal process, providing legal consultation to the victim, accompanying and defending the victim in every legal process by legal counselor. Non-legal assistance provided to victims is psychological assistance and medical assistance. Psychological accompaniment is preceded by an assesment (guessing) from the psychologist to the situation of the victim, then psychologist will do the diagnosis to the victim, after that the intervention to the victim or the people closest to the victim. Psychological accompaniment aims to help the victim to get her psychic condition back better or the victim can empower herself back. Psychological assistance is done through referral P2TP2A on psychologists who are in the Regional Hospital.

\section{B. Effective Communication of P2TP2A Serdang Bedagai on Victim Families of Sexual Violence in Case Handling}

P2TP2A Serdang Bedagai District recognizes the target of communication (victim) through the report of the Women and Child Protection Unit (PPA) of the Serdang Bedagai Police, Society or a direct complaint from P2TP2A Serdang Bedagai District. In handling child victims of sexual violence, officers pay attention first to the frame of reference of each child victims of sexual violence reported in the background, chronological events and its situations and conditions. P2TP2A Serdang Bedagai District conducts face-to-face media or directly with child victims of sexual violence through counseling meetings. In counseling meetings, the victim will explore his feelings about the problems he faces and things that have not been explored by the police.

Researchers also found that P2TP2A Serdang Bedagai district using media supporters in the process of mentoring through the media play like coloring and drawing. The choice of this media depends on the age of the child of the victim of sexual violence and the character of the child. For children aged under 9 years, coloring and drawing media is the choice of their communication media. If the victim is still traumatized, then the officer will give more approach in communication to the victim's family to find out various informations related to the chronology of the incident.

Based on the research results obtained that P2TP2A Serdang Bedagai District as a communicator, they can do better communication to child victims of sexual violence that has been accompanied it. The P2TP2A of Serdang Bedagai Regency in digging information about child victims of sexual violence is not like interrogating the child of the victim of sexual violence, they have to protect the privacy and confidentiality of victim and family. This is consistent with what Jalaluddin Rakhmat discloses that the most important indicator in the communicator is credibility which is about trust and expertise. Berlo in Hafied Cangara adds that the credibility of a communicator can arise if he has communication skills (communication skills), extensive knowledge of his material (knowledge), honest attitude and friendly (attitude), and be able to adapt to social and cultural system (social and culture system) of the society it faces.

Several things are still a highlight in the communication process conducted by $\mathrm{P} 2 \mathrm{TP} 2 \mathrm{~A}$ institutions to victims of violence. This is because the number of personnel in P2TP2A institutions is still limited, so communication in the process of trauma healing on the victim is still not effectively executed. Communication is mostly done to get information about chronological events. Communication as an effort to deepen the psychological condition of victims still tends to be ignored. Although, P2TP2A institutionally has referral of victim to psychologist at Regional Hospital, but this has not been executed maximally.

Communications run by $\mathrm{P} 2 \mathrm{TP} 2 \mathrm{~A}$ institutions on victims and families of victims is more intense about legal aid process conducted by P2TP2A institution in providing services of handling of sexual violence that happened. In the research process, it is found also some cases where the legal aid process is still not maximum because it is also a shortage of human resources experts in handling this law.

\section{CONCLUSION}

The strategy to identify the target of P2TP2A communication of Serdang Bedagai District in assisting child victims of sexual violence is to receive information in advance of report from Unit of Women and Child Protection (PPA) Polres Serdang Bedagai, community or complaint directly from victim's parents / family to P2TP2A Serdang Bedagai . After that, paying attention to the factors of child victims of sexual violence which has been reported in the form of reference frame factors, among others, the background of the child victims of sexual violence and chronological events. Moreover, the situation of the child victims of sexual violence in the form of place and meeting room of child victims of sexual violence, physical and psychological condition of child victims of sexual violence. Institutional P2TP2A in preventing and handling of cases of sexual violence has a good communication procedure. However, based on the results of research, communication run 
by institutions P2TP2A still not running optimally due to the limited expert personnel in the institutional.

\section{ACKNOWLEDGMENT}

The authors would like to thank the Ministry of Research, Technology and Higher Education, the Research Institute of the University of North Sumatra for their financial support in this research and the Serdang Bedagai District Government and P2TP2A Serdang Bedagai for their support and participation in this research activity. The authors are also grateful to the victims and the victim's family for their helpful work.

\section{REFERENCES}

[1] Cangara, Hafied. (2013). Perencanaan \& Strategi Komunikasi. Jakarta: Rajawali Pers.

[2] Indrawati (2017) Studi Tentang Pusat Pelayanan Terpadu Pemberdayaan Perempuan dan Anak (P2TP2A) dalam Penanganan Tindak Kekerasan Terhadap Perempuan di Kabupaten Bontang. eJournal Administrasi Negara. Volume 5, (Nomor 2) 2017: 5747-5761.

[3] Misriyani Hartati (2013) Studi Tentang Upaya Penanganan Tindak Kekerasan Terhadap Perempuan dan Anak (Studi Kasus Pada Pusat Pelayanan Terpadu Pemberdayaan Perempuan dan Anak (P2TP2A) Provinsi Kalimantan Timur). eJournal Ilmu Pemerintahan. Volume 1 (3): 1094-1106

[4] Syawaluddin Nasution, \& Tuti Khairani (2015) Kinerja Pusat Pelayanan Terpadu Pemberdayaan Perempuan dan Anak (P2TP2A) dalam Menangani Kekerasan Terhadap Perempuan dan Anak di Provinsi Riau (Studi Kasus Kota Pekanbaru). eJournal Ilmu Pemerintahan. Volume 1 (3): 1094-1106. 